\title{
PENGARUH MOTIVASI KERJA DAN KEPEMIMPINAN TERHADAP KINERJA DOSEN STMIK KHARISMA KARAWANG
}

\author{
Dedi Supriadi ${ }^{1}$ \\ Dosen STMIK Kharisma Karawang \\ dedidevan9@gmail.com \\ Prof.Dr. H.A Noesyirwan Moeis, M.SC, M.M² \\ H. Dwiono, M.Pd M ${ }^{3}$
}

\begin{abstract}
ABSTRAK
Penelitian ini bertujuan untuk mengetahui pengaruh motivasi kerja dan kepemimpinan baik secara parsial maupun secara bersama-sama dengan kinerja dosen STMIK Kharisma Karawang. Dalam penelitian ini populasi yang dimaksud adalah seluruh dosen STMIK Kharisma Karawang baik dosen tetap dan dosen tidak tetap. Sampel diambil dari seluruh jumlah dosen sebanyak 35 dosen.

Dari hasil penelitian diperoleh koefesien korelasi untuk variabel motivasi kerja $\left(\mathrm{X}_{1}\right)$ terhadap kinerja dosen sebesar 0,827 dengan tingkat signifikansi sebesar 5\%, koefesien korelasi untuk variabel kepemimpinan $\left(\mathrm{X}_{2}\right)$ sebesar 0,758 dengan tingkat signifikansi sebesar 5\% sedangkan nilai koefisiensi korelasi (R) sebesar 0,779 Atau $77,9 \%$ yang berarti mempunyai pengaruh yang kuat antara variabel bebas dan variabel terikat, juga diperoleh koefesien detirminasi $\left(R^{2}\right)$ sebesar 0,607 . Nilai ini dapat ditafsirkan bahwa besarnya persentase mempunyai pengaruh antara variabel motivasi kerja dan kepemimpinan secara bersama-sama dengan kinerja dosen adalah 3,09 Dengan kata lain kontribusi efektif motivasi kerja dan kepemimpinan terhadap kinerja dosen STMIK Kharisma Karawang adalah sebesar $60,7 \%$ sedangkan selebihnya $30,3 \%$ dipengaruhi oleh variabel lain yang tidak dimasukkan dalam penelitian ini.

Hasil penelitian ini diharapkan sebagai bahan masukan bagi STMIK Kharisma Karawang bahwa kinerja dosen akan membawa perubahan yang lebih baik
\end{abstract}

\section{A. Latar Belakang Masalah}

Proses Pendidikan sangat dipengaruhi oleh kinerja dosen untuk keberhasilan proses belajar mengajar, terkadang kinerja dosen tidak bisa dipandang stabil karena ada kalanya kinerja tersebut naik dan turun, Kinerja merupakan penampilan hasil kerja baik secara kuantitas maupun kualitas. Kinerja dapat berupa penampilan kerja perorangan maupun kelompok menyatakan kinerja merujuk kepada pencapaian tujuan dosen atas tugas yang diberikan.

Dosen adalah bagian dari organisasi dalam meningkatkan mutu pendidikan diperguruan tinggi maka dibutuhkan kinerja dosen yang mampu membawa perubahan yang lebih baik. Kinerja dosen perlu diperhatikan dan mendapat perhatian khusus terutama dalam merefleksikan kepada mahasiswa dalam bahan pengajaran supaya sesuai target yang diharapkan.

Seorang dosen membutuhkan Emotional Quetiont (EQ) tinggi karena kinerja dosen mewakili organisasi. Berinteraksi dengan banyak orang baik di dalam maupun di luar organisasi, dan berperan penting dalam membentuk moral dan disiplin para peserta didik. Dosen yang memiliki empati akan dapat memahami kebutuhan peserta didik dan dapat memberikan feedback (unpan balik) yang konstruktif. Untuk dapat sukses dibidang 
pendidikan dituntut kemampuan berempati guna mengetahui peserta didik dan kemampuan interpersonal guna tercapainya kegiatan belajar mengajar. Dipihak lain kinerja dosen yang profesional dituntut untuk memiliki disiplin diri dan motivasi yang tinggi.

Berdasarkan pokok pemikiran di atas, maka sangat jelas bahwa motivasi kerja, kepemimpinan memiliki pengaruh terhadap kelangsungan dosen dalam mengemban tugas di STMIK Kharisma Karawang. Demikian halnya dengan kinerja dosen ditentukan oleh tingkat sejauh mana motivasi kerja dan kepemimpinan di lingkungan kerjanya. Berkaitan dengan latar belakang di atas penulis bermaksud mengadakan penelitian dengan judul " PENGARUH MOTIVASI KERJA DAN KEPEMIMPINAN TERHADAP KINERJA DOSEN STMIK KHARISMA KARAWANG "

\section{B. Rumusan Masalah}

Berdasarkan kondisi dan situasi yang telah dijelaskan dalam latar belakang masalah, identifikasi masalah dan batasan masalah maka terdapat beberapa permasalahan yang perlu diperhatikan sebagai penentuan pembahasan penelitian. Dalam hal ini rumusan masalah yang di tampilkan penulis yaitu dalam bentuk pertanyaan yang akan mengarah pada tujuan penelitian itu sendiri antara lain:

1. Apakah terdapat pengaruh motivasi kerja terhadap kinerja dosen STMIK Kharisma Karawang?

2. Apakah terdapat pengaruh kepemimpinan terhadap kinerja dosen STMIK Kharisma Karawang?

3. Apakah terdapat pengaruh motivasi dan kepemimpinan terhadap kinerja dosen STMIK Kharisma Karawang?

\section{Tujuan Penelitian}

Penelitian ini dimaksudkan untuk mengetahui Pengaruh Motivasi Kerja, Kepemimpinan dan Kinerja Dosen STMIK Kharisma Karawang dalam rangka meningkatkan mutu pendidikan. Adapun Tujuan yang ingin dicapai penelitian ini adalah sebagai berikut yaitu :

1. Untuk mengetahui pengaruh motivasi kerja terhadap kinerja dosen STMIK Kharisma Karawang.

2. Untuk mengetahui pengaruh kepemimpinan terhadap kinerja dosen STMIK Kharisma Karawang.

3. Untuk mengetahu motivasi kerja dan kepemimpinan terhadap kinerja dosen STMIK Kharisma Karawang.

\section{Tinjauan Pustaka}

\section{Motivasi Kerja}

Faktor penting yang mempengaruhi prestasi kerja adalah motivasi kerja. Motivasi berasal dari kata motive. Motive adalah keadaan dalam diri seseorang yang menimbulkan kekuatan, menggerakkan, mendorong, mengarahkan, motivasi. Menurut Gerungan motivasi adalah sesuatu yang menimbulkan semangat atau dorongan kerja (Gerungan, 1982: 23). Semakin besar motivasi kerja karyawan semakin tinggi prestasi kerjanya.

Dengan demikian dapat dikatakan bahwa motivasi kerja adalah faktor yang sangat penting dalam peningkatan prestasi kerja. Selain ditentukan oleh motivasi kerjanya, prestasi kerja karyawan juga ditentukan oleh kepuasan kerjanya. Kepuasan kerja adalah keadaan emosional yang menyenangkan dengan mana para karyawan memandang pekerjaan mereka (As'ad, 2000: 133). Kepuasan kerja mencerminkan perasaan seseorang terhadap pekerjaannya. Ini nampak dari sikap karyawan terhadap pekerjaan dan segala sesuatu di lingkungan kerjanya.

Menurut Handoko (2000: 193). Menjadi kewajiban setiap pemimpin perusahaan untuk menciptakan kepuasan kerja bagi para karyawannya, karena kepuasan kerja 
merupakan faktor yang diyakini dapat mendorong dan mempengaruhi semangat kerja karyawan agar karyawan dapat bekerja dengan baik dan secara langsung akan mempengaruhi prestasi karyawan. Seorang pimpinan juga dituntut agar memberikan suasana kerja yang baik dan menyenangkan juga jaminan keselamatan kerja sehingga karyawan akan merasa terpuaskan.

Menurut Handoko bagi mayoritas karyawan, uang masih tetap merupakan motivasi kuat atau bahkan paling kuat (Handoko, 2000: 176). Atas dasar itulah diperkirakan pemberlakuan sistem insentif akan mampu membuat karyawan termotivasi untuk meningkatkan prestasi kerjanya, yang pada akhirnya akan memberikan dampak positif. Orang - orang tidak hanya berbeda dalam kemampuan melakukan sesuatu tetapi juga dalam motivasi mereka melakukan motif berarti suatu keadaan di dalam diri seseorang (inner state) yang mendorong, mengaktifkan, menggerakkan, mengarahkan dan menyalurkan kearah tujuan (Koontz,2000:115)

Peranan manusia dalam mencapai tujuan tersebut sangat penting dalam pencapaian tujuan organisasi. Untuk menggerakkan manusia agar sesuai dengan yang dikehendaki organisasi, maka haruslah dipahami motivasi manusia bekerja pada suatu organisasi, karena motivasi inilah yang menentukan perilaku orang - orang untuk bekerja atau dengan kata lain perilaku merupakan cerminan yang paling sederhana dari motivasi. Adapun beberapa pengertian motivasi adalah sebagai berikut:

Motivasi berarti sesuatu hal yang menimbulkan dorongan atau keadaan yang menimbulkan dorongan. Jadi motivasi dapat pula diartikan faktor yang mendorong orang untuk bertindak dengan cara tertentu. (Manullang, 2000 : 76)

Motivasi seringkali di artikan dengan istilah dorongan. Dorongan atau tenaga tersebut merupakan jiwa dan jasmani untuk berbuat mencapai tujuan, sehingga motivasi merupakan suatu driving force yang menggerakkan manusia untuk bertingkah laku, dan di dalam pebuatannya itu mempunyai tujuan tertentu. (As'ad, 1995: 45)

Dari beberapa definisi tentang motivasi sebelumnya dalam penelitin ini motivasi kerja adalah suatu dorongan kebutuhan dan keinginan individu yang diarahkan pada tujuan untuk memperoleh kepuasan dari apa yang dibutuhkannya dosen agar mau bekerja secara profesional demi tercapainya tujuan organisasi

\section{Kepemimpinan}

Kepemimpinan dalam bahasa inggris di disebut leadership artinya adalah kata benda (noun) yang berasal dari kata kerja (verb) to lead yang secara harapiah memiliki banyak makna, diantaranya: Menyebabkan, menuntun, memimpin, menggiring, mengarahkan, dan memenangkan (Echols and Shadily, 1997; h. 351)

Kepemimpinan adalah kemampuan seseorang untuk mempengaruhi atau mengajak orang lain (pengikut anak buah) untuk mencapai tujuan kelompok suatu orgnisasi. Menurut Drucker Peran seorang pemimpin dalam sebuah orgnisasi sangat penting karena pemimpin adalah orang yang mampu mengubah keadaan (makes thing happen) melalui pencapain tujuan organisasi.

Menurut Smircich dan Morgan ,1982,p.258

"Kepemimpinan diwujudkan dalam proses dimana satu atau lebih individu berhasil dalam kelompok dan menyadari realitas kehadiran orang lain"

Menurut Rauch dan Behling, 1984,h.46

"Kepemimpinan adalah proses mempengaruhi kegiatan kelompok yang terorganisir menuju pencapaian tujuan"

Menurut Drath dan Palus, 1994,h.4

"Kepemimpinan adalah proses untuk memahami apa yang dilakukan orang bersama sehingga orang akan memahami dan berkomitmen". 
Menurut Lussier N.Robert \& Cristoper F.Achua, 2007, h. 6

Kepemimpinan adalah " proses mempengaruhi antara pimpinan denan pengikut untuk mencapai tujuan organisasi melalui perubahan"

Berdasarkan definisi-definisi tersebut kepemimpinan dalam penelitian ini adalah:

a. Kepemimpinan berarti melibatkan orang atau pihak lain, yaitu para bawahan dan dosen.

Para bawahan dan dosen harus memiliki kemauan untuk menerima arahan dari pemimpin. Walaupun demikian, tanpa adanya bawahan dan dosen tidak akan ada pimpinan.

b. Kepemimpinan harus memiliki kejujuran terhadap diri sendiri (integrity), sikap bertanggung jawab yang tulus ( compassion), pengetahuan, keberanian bertindak sesuai dengan keyakinan (commitment), kepercayaan pada diri sendiri dan orang lain (confidence) dan kemampuan untuk meyakinkan orang lain (communication) dalam membangun organisasi

\section{Kinerja}

Istilah kinerja berasal dari kata "performance", yang sering disebut juga dengan istilah umum seperti unjuk kerja, prestasi kerja, pencapaian pelaksanaan kerja, hasil kerja, output, penampilan kerja. Jadi pengertian kinerja adalah hasil kerja yang sesuai dengan sasaran-sasaran yang ingin dicapai dan standar kinerja yang ditetapkan yang disebut kinerja tinggi (high performance).

Beberapa teori kinerja diantaranya:

"Kinerja yaitu catatan hasil (out come) yang dihasilkan dari fungsi suatu pekerjaan atau suatu kegiatan tertentu selama suatu periode waktu tertentu"

Anwar Prabu Mangkunegara (2000: 67)

" Kinerja (prestasi kerja) adalah hasil kerja secara kualitas dan kuantitas yang dicapai oleh seseorang pegawai dalam melaksanakan tugasnya sesuai dengan tanggung jawab yang diberikan kepadanya."

Kinerja merupakan suatu kondisi yang harus diketahui dan diinformasikan kepada pihak tertentu untuk mengetahui tingkat pencapaian hasil suatu instansi dihubungkan dengan visi yang diemban suatu organisasi atau perusahaan serta mengetahuin dampak positif dan negatif dari suatu kebijakan operasional. Mink ( 1993 : 76 ) mengemukakan pendapatnya bahwa individu yang memiliki beberapa karakteristik, yaitu diantaranya berorientasi pada prestasi, memiliki percaya diri, pengendalian diri dan kompetensi.

Untuk organisasi-organisasi, di mana hasil kerjanya tidak dapat diukur secara kuantitatif, tetapi hanya dengan pertimbangan (judgment) saja, kinerja di sini dapat berarti perilaku di tempat kerja (workplace behavior) atau penampilan kerja, dan dapat juga berarti proses kerja dalam bentuk SOP (Standard Operation Prosedures) yang didasarkan pada uraian pekerjaan (job description). Umumnya, pada instansi pemerintah, karena sifat hasil kerja adalah pelayanan, maka sukar untuk melakukan pengukuran (measurement), tetapi dapat dilakukan pertimbangan (judgement) terhadap perilaku-perilaku di tempat kerja atau terhadap prosedur dan proses kerja.

Kecenderungan manusia memberikan pertimbangan terhadap siapa yang dapat menciptakan motivasi, etika, dan aturan-aturan di tempat kerja. Tanpa suatu sistem penilian terstruktur, sedikit kemungkinan dapat menjamin pertimbangan yang diberikan akan sah menurut hukum, adil, dapat bertahan dan akurat.terhadap diri sendiri. Penilaian, merupakan sesuatu yang tidak dapat dihindarkan dan bersifat universal. Apabila tidak ada suatu sistem penilaian yang terstruktur dan cermat, Menurut penulis kinerja dapat didefinisikan yaitu suatu hasil dimana orang-orang dan sumber daya lain yang ada dalam perguruan tinggi secara bersama-sama membawa hasil akhir yang didasarkan pada tingkat mutu dan standar yang telah di tetapkan. 


\section{E. Metode Penelitian}

Variabel-variabel yang terdapat dalam penelitian ini meliputi variabel bebasnya adalah motivasi kerja dan kepemimpinan kemudian variabel terikatnya adalah kinerja. Populasi penelitian ini dilakukan di STMIK Kharisma karawang dan penelitian ini terdiri dari 35 orang dosen. Alat yang digunakan untuk mengumpulkan data dalam penelitian ini menggunakan data skala yaitu data tentang motivasi kerja, kepemimpinan dan kinerja dosen. Teknik analisis statistik yang dipakai untuk menguji hipotesis yang telah ditetapkan adalah teknik korelasi regresi berganda.

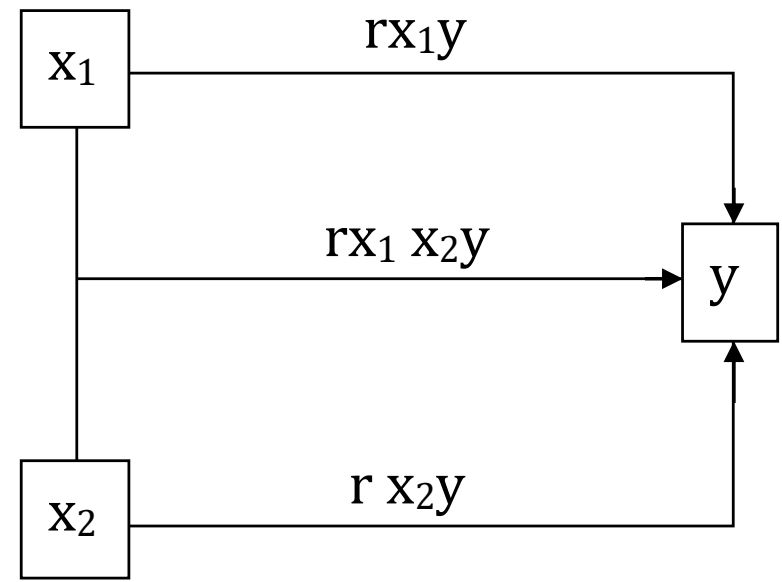

$\mathrm{r}=$ koefisien korelasi

Keterangan

$\mathrm{X}_{1}=$ Motivasi Kerja

$\mathrm{X}_{2}=$ Kepemimpinan

$\mathrm{Y}=$ Kinerja

Sebelum kuesioner disebarkan terlebih dahulu akan diuji reliabilitas dan validasi kuesioner tersebut, dari 35 jumlah responden dapat diketahui hasilnya bahwa semua instrument penelitian semuanya sudah valid dan reliable.

\section{F. Analisis Regresai Berganda}

Analisis ini digunakan untuk menguji apakah ada hubungan antara variabel bebas motivasi $\left(\mathrm{X}_{1}\right)$ dan kepemimpinan $\left(\mathrm{X}_{2}\right)$, secara bersama-sama terhadap variabel terikat kinerja dosen $(\mathrm{Y})$, serta untuk mengetahui kuat tidaknya hubungan antara variabel bebas terhadap variabel terikat. Rumus umum dari regresi linier berganda seperti yang dikutip (sudjana 2002:h.312) adalah sebagai berikut :

Pengaruh $\mathrm{X}_{1}$ terhadap $\mathrm{Y}$

Pengaruh $\mathrm{X}_{2}$ terhadap $\mathrm{Y}$

$\mathrm{Y}=\mathrm{a}+\mathrm{b} \mathrm{X}_{1}$

$\mathrm{Y}=\mathrm{a}+\mathrm{b} \mathrm{X}_{2}$

$\mathrm{Y}=\mathrm{b}_{\mathrm{o}}+\mathrm{b}_{1} \mathrm{X}_{1}+\mathrm{b}_{2} \mathrm{X}_{2}$

Keterangan : 


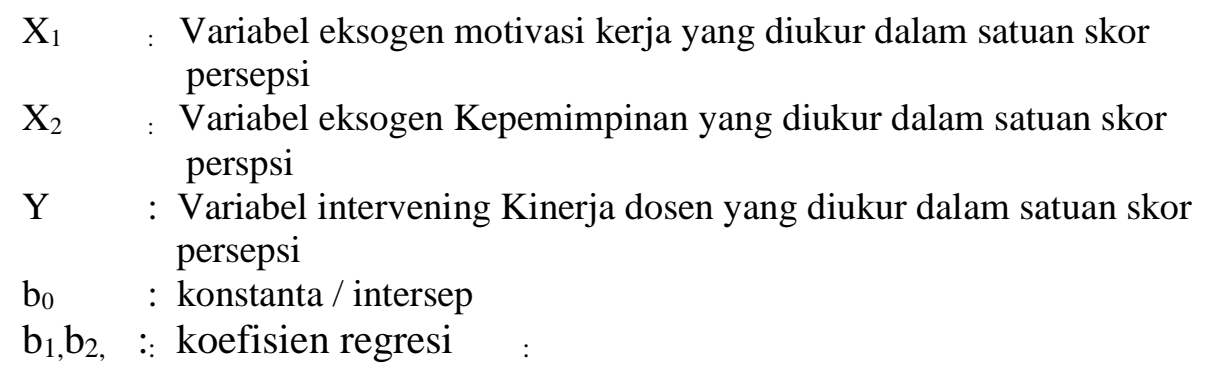

\section{G. Analisis Korelasi}

Sedangkan di dalam koefesien korelasi ( $\mathrm{r}$ ) menggunakan metode product moment ( Husein Umar 1999 : 195 ), tujuannya untuk menentukan besarnya besaran. Metode ini berguna menyatakan bagaimana pengaruh hubungan suatu variabel yang satu dengan variabel yang lainnya, dalam hal ini motivasi, kepemimpinan dengan kinerja dosen dimana perhitungannya digunakan rumus sebagai berikut

$$
r x y=\frac{\mathrm{n} \sum \mathrm{xy}-\sum \mathrm{x} \sum \mathrm{y}}{\sqrt{\left(\mathrm{n} \sum \mathrm{x}^{2}-\left(\sum \mathrm{x}\right)^{2}\right)\left(\mathrm{n} \sum \mathrm{y}^{2}-\left(\sum \mathrm{y}\right)^{2}\right.}}
$$

Keterangan :

$$
\begin{array}{ll}
\mathrm{r} & \text { : Korelasi } \\
\mathrm{X} & \text { : Variabel bebas (motivasi, kepemimpinan) } \\
\mathrm{Y} & \text { : Variabel tetap (kinerja dosen) } \\
\mathrm{n} & \text { : Jumlah sampel } \\
\sum \mathrm{x}^{2} & \text { : Jumlah nuadrat nilai } \mathrm{x} \\
\sum \mathrm{y}^{2} & \text { : Jumlah nuadrat nilai } \mathrm{y}
\end{array}
$$

Keeratan hubungan antara variabel tersebut secara matematis dinyatakan sebagai - $1<$ $r>1$. Semakin jauh angket $r$ dan nol, maka semakin dekat atu erat hubungan antara variabel - variabel tersebut :

$\mathrm{r}=0>0$, Menunjukan hubungan positif

$\mathrm{r}=0<0$, Menunjukan hubungan negatif

$r=0 \quad 0$, Menunjukan tidak ada hubungan

\section{Populasi}

Menurut Sujana (2002:h.3) sumber data yang didapati dalam suatu penelitian disebut populasi, atau jumlah keseluruhan dari objek yang diteliti. Populasi merupakan keseluruhan dari unit analisis / hasil pengukuran yang dibatasi oleh kriteria tertentu, sedangkan sampel adalah sekumpulan / sebagian dari unit - unit populasi yang diperoleh melalui proses sampling tertentu. Lebih jelas, Sugiyono, (2006 : 55) memberikan definisi populasi sebagai wilayah generalisasi yang terdiri atas objek / subjek yang mempunyai

\begin{tabular}{|c|c|c|}
\hline $\mathrm{NO}$ & Dosen & Jumlah \\
\hline 1 & Dosen Tetap & 26 Orang \\
\hline 2 & Dosen Tidak Tetap & 9 Orang \\
\hline \multicolumn{2}{|r|}{ Jumlah } & 35 Orang \\
\hline
\end{tabular}
kuantitas dan karakteristik tertentu yang ditetapkan oleh peneliti untuk dipelajari dan kemudian ditarik kesimpulannya.

Populasi dalam penelitian ini adalah dosen STMIK Kharisma Karawang yang berjumlah 35 orang dengan rincian sebagai berikut.

Tabel

Populasi Penelitian 
Sumber Data Tahun 2018

\section{Teknik Pengambilan Sampel}

Sampel menurut beberapa ahli adalah bagian dari suatu populasi. Sampel tersebut merupakan sumber data yang dikumpulkan sehingga menunjukan populasi yang memiliki semua data dihimpun dengan menggunakan kuesioner yang bersifat tertutup. Kuesioner terdiri dari 35 dosen STMIK Kharisma Karawang. Pertanyaan motivasi kerja 25 pertanyaan, kepemimpinan 25 pertanyaan dan 25 pertanyaan untuk kinerja dosen. Total seluruh pertanyaan 75 pertanyaan. Struktur pertanyaan disusun dengan menggunakan kalimat positif, serta disusun menurut skala Likerts. Skala Likerts digunakan karena penelitian ini akan mengukur sikap, pendapat, atau persepsi seseorang tentang fenomena sosial (Sugiono, 2000 : 67). Setiap pertanyaan dalam kuesioner yang telah dijawab oleh responden akan diberikan bobot angka dengan kriteria skala likert sebagai berikut :

Tabel.

Skala Pertanyaan

\begin{tabular}{|l|c|c|c|c|c|}
\hline \multicolumn{1}{|c|}{ Variabel } & 1 & 2 & 3 & 4 & 5 \\
\hline Motivasi Kerja $\left(\boldsymbol{X}_{\boldsymbol{I}}\right)$ & $\mathrm{TP}$ & $\mathrm{JR}$ & $\mathrm{KD}$ & $\mathrm{SR}$ & SL \\
\hline Kepemimpinan $\left(\mathrm{X}_{2}\right)$ & $\mathrm{TP}$ & JR & KD & SR & SL \\
\hline Kinerja Dosen $(\mathrm{Y})$ & $\mathrm{TP}$ & $\mathrm{JR}$ & $\mathrm{KD}$ & $\mathrm{SR}$ & SL \\
\hline & & & & & \\
\hline
\end{tabular}

$\begin{array}{ll}\text { Keterangan : } \\ \text { TP } & \text { : Tidak pernah } \\ \text { JR } & \text { : Jarang } \\ \text { KD } & \text { : Kadang-kadang } \\ \text { SR } & \text { : Sering } \\ \text { SL } & \text { : Selalu }\end{array}$

\section{H. Definisi Konseptual dan Operasional Variabel}

\section{Motivasi Kerja}

Variabel motivasi kerja merupakan variabel independen (bebas), dimana motivasi dapat dilihat dari beberapa dimensi. Dimensi ekstrinsik yaitu dari lembaga itu sendiri mencakup gaji. bonus, tunjangan, konpensasi, nyaman bekerja, kelengkapan dan lama bekerja. Indikator intrinsik yaitu dari dosen itu sendiri dalam berprilaku antara lain disiplin kerja, melakukan pekerjaan sesuai intruksi, kemampuan dalam menyelesaikan pekerjaan, penilaian, prestasi.

\section{Kepemimpinan}

Variabel kepemimpinan merupakan variabel independen (bebas), Dimensi kepemimpina ialah manajerial dan organisasi, komunikasi, kebijakan, menyelesaikan konflik. Aturan dan tata tertib mencakup sanksi, komitment dan kedisiplinan hak dan kewajiban,, keberanian bertindak sesuai dengan keyakinan, kemampuan untuk meyakinkan orang

\section{Kinerja}

Variabel kinerja dosen merupakan variable dependent (terikat), cara mengukur kinerja yaitu disiplin, tingkat penyelesaian pekerjaan, ketepatan waktu, efektifitas, kemandirian, kerjasama antara rekan kerja dan afektif 


\section{Instrumen Penelitian}

Dalam penelitian ini yang menjadi variabel terikat adalah kinerja $(\mathrm{Y})$ dan yang menjadi variabel bebasnya yaitu motivasi $\left(\mathrm{X}_{1}\right)$ dan kepemimpinan $\left(\mathrm{X}_{2}\right)$.

Kemudian Indikator-indikator variabel dalam penelitian ini seperti terlihat pada tabel di bawah ini :

Tabel. 1

Tabel Kisi-Kisi Variabel Motivasi Kerja $\left(\mathrm{X}_{1}\right)$

\begin{tabular}{|c|c|c|c|}
\hline Variabel & Dimensi & Indikator & Butir Pertanyaan \\
\hline \multirow[t]{2}{*}{ Motivasi Kerja $\left(\mathrm{X}_{1}\right)$} & 1. Ekstrinsik & $\begin{array}{ll}\text { 1. } & \text { Gaji/honor } \\
\text { 2. } & \text { Tunjangan } \\
\text { 3. } & \text { Insentif } \\
\text { 4. } & \text { Konpensasi } \\
\text { 5. } & \text { Peraturan gaji } \\
\text { 6. } & \text { Lama kerja } \\
\text { 7. } & \text { Pengalaman } \\
\text { 8. } & \text { Penghargaan prestasi } \\
\text { 9. } & \text { Kemampuan }\end{array}$ & 1 s.d 12 \\
\hline & 2. Intrinsik & $\begin{array}{l}\text { 10. Disiplin kerja } \\
\text { 11. Melakukan pekerjaan } \\
\text { sesuai intruksi } \\
\text { 12. Kreativitas } \\
\text { 13. Kemampuan dalam } \\
\text { menyelsaikan tugas } \\
\text { 14. Penilaian }\end{array}$ & 13 s.d 25 \\
\hline
\end{tabular}

Tabel. 2

Tabel Kisi-Kisi Variabel Kepemimpinan $\left(\mathrm{X}_{2}\right)$

\begin{tabular}{|c|c|c|c|}
\hline Variabel & Dimensi & Indikator & $\begin{array}{c}\text { Butir } \\
\text { Pertanyaan }\end{array}$ \\
\hline \multirow[t]{2}{*}{ Kepemimpinan $\left(\mathrm{X}_{2}\right)$} & $\begin{array}{l}\text { Manajerial } \\
\text { organisasi }\end{array}$ & $\begin{array}{ll}\text { 1. } & \text { Tugas dan tanggung } \\
& \text { jawab } \\
\text { 2. } & \text { Pengambilan } \\
& \text { keputusan } \\
\text { 3. } & \text { Iklim kerja } \\
\text { 4. } & \text { Kondisi kerja } \\
\text { 5. } & \text { Pengalaman organisasi } \\
\text { 6. } & \text { Penyelesaian tugas }\end{array}$ & 1 s.d 15 \\
\hline & $\begin{array}{l}\text { 2. Membangun } \\
\text { organisasi }\end{array}$ & $\begin{array}{ll}\text { 7. } & \text { Aturan dan tata tertib } \\
\text { 8. } & \text { Sanksi } \\
\text { 9. } & \text { Komitmen } \\
\text { 10. } & \text { Hak dan kewajiban } \\
\text { dosen }\end{array}$ & 16 s.d 25 \\
\hline
\end{tabular}

Tabel.3

Tabel Kisi-Kisi Variabel Kinerja Dosen (Y)

\begin{tabular}{|c|c|c|c|}
\hline Variabel & Dimensi & Indikator & $\begin{array}{c}\text { Butir } \\
\text { Pertanyaan }\end{array}$ \\
\hline Kinerja Dosen (Y) & $\begin{array}{l}\text { 1. Kemampuan } \\
\text { melaksanakan pekerjan }\end{array}$ & $\begin{array}{ll}\text { 1. } & \text { Tepat waktu } \\
\text { 2. } & \text { Loyalitas pekerjaan } \\
\text { 3. } & \text { Sesuai target } \\
\text { 4. } & \text { Kemauan yang keras } \\
\text { 5. } & \text { Kreatif }\end{array}$ & 1 s.d 5 \\
\hline
\end{tabular}




\begin{tabular}{|c|c|c|}
\hline $\begin{array}{l}\text { 2. Keilmuan dan kemampuan } \\
\text { memberikan materi }\end{array}$ & $\begin{array}{l}\text { 6. Penyampaian materi } \\
\text { 7. Bahasa yang } \\
\text { disampaikan } \\
\text { 8. Penguasaan bahan } \\
\text { materi } \\
\text { 9. Kelengkapan bahan }\end{array}$ & 6 s.d 11 \\
\hline $\begin{array}{l}\text { 3. Kerjasama dalam } \\
\text { kelompok }\end{array}$ & 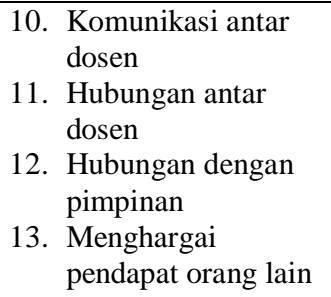 & 12 s.d 16 \\
\hline $\begin{array}{l}\text { 4. Upaya memperbaiki diri } \\
\text { sendiri }\end{array}$ & $\begin{array}{l}\text { 14. Ramah } \\
\text { 15. Teladan } \\
\text { 16. Sopan santun } \\
\text { 17. Berpenampilan } \\
\text { rapih } \\
\text { 18. Aktualisasi }\end{array}$ & 18 s.d 25 \\
\hline
\end{tabular}

Salah satu instrumen yang sering dipakai dalam penelitian ilmiah adalah angket, yang bertujuan untuk mengetahui pendapat seseorang mengenai sesuatu hal, dalam penelitian ini mengenai motivasi, kepemimpinan sebagai variabel bebas (idenpendent variable) dan kinerja dosen sebagai variabel terikat (dependent variable). angket disusun dengan menggunakan skala Likert yang berisi lima tingkat jawaban yang merupakan skala jenis interval, mulai dari yang paling rendah yaitu tidak pernah $=1$ kepada yang paling tinggi yaitu sangat baik $=5$.

Ada dua syarat penting yang berlaku pada sebuah angket, yaitu keharusan sebuah angket untuk valid dan reliabel.

Suatu angket dikatakan valid jika pertanyaan pada suatu angket mampu mengungkapkan sesuatu yang akan diukur oleh angket tersebut (Santoso, 2001). Suatu angket dikatakan reliabel jika jawaban seseorang terhadap pertanyaan adalah konsisten atau stabil dari waktu kewaktu (Santoso, 2001).

Pengujian validitas dan reliabilitas adalah proses menguji butir-butir pertanyaan yang ada dalam sebuah angket, apakah isi dari butir-butir pertanyan tersebut sudah valid dan reliabel untuk mengukur faktor-faktor atau konstrak. Pengukuran dilakukan dengan menggunakan metode Reliability Analysis-Scale (Alpha) dengan bantuan program SPSS versi 11.50 .

\section{J. Hasil Penelitian}

\section{Uji Validitas}

Dalam melakukan analisis data dan guna membahas pertanyaan, maka langkah pertama adalah dengan menguji validitas yang menunjukkan sejauh mana suatu alat ukur itu mengukur construck yang akan diukur pengujian item homogenitas dilakukan dalam pengujian validitas. Untuk pertanyaan yang digunakan untuk mengukur suatu variabel, pengujian scor item homogenitas dari item menunjukkan bahwa skor pertanyaan-pertanyaan dalam variabel motivasi kerja, kepemimpinan dan kinerja dosen mempunyai instrument yang valid. 
a. Motivasi Kerja $\left(\mathrm{X}_{1}\right)$

Dari perhitungan data didapat bahwa peneliti melakukan uji validitas variabel $\mathrm{X}_{1}$ yang dilakukan terhadap 35 orang dosen menunjuukan item instrumen valid dan signifikan karena nilai sig $>0,05$. Hasil pengujian validitas dapat dilihat dalam lampiran.

b. Variabel Kepemimpinan $\left(\mathrm{X}_{2}\right)$

Dari perhitungan data didapat bahwa peneliti melakukan uji validitas variabel $\mathrm{X}_{2}$ yang dilakukan terhadap 35 orang dosen menunjukkan item instrumen valid dan signifikan karena nilai sig $>0,05$. Hasil pengujian validitas dapat dilihat dalam lampiran.

c. Variabel Kinerja Dosen (Y)

Dari perhitungan data didapat bahwa peneliti melakukan uji validitas variabel $\mathrm{Y}$ yang dilakukan terhadap 35 orang dosen menunjukkan item instrumen valid dan signifikan karena nilai sig $>0,05$. Hasil pengujian validitas dapat dilihat dalam lampiran.

\section{Uji Reliabilitas}

Uji Reliabilitas adalah ukuran konsisten instrument penelitian, instrument dinyatakan reliable jika alat ukur yang digunakan aman kerena bekerja dengan baik pada waktu dan kondisi yang berbeda, hasil pengujian reliabilitas menunjukkan bahwa seluruh item yaitu 75 pernyataan menunjukkan bahwa 25 pernyataan dari variabel motivasi kerja, 25 pertanyaan dari variabel kepemimpinan dan 25 pertanyaan dari variabel kinerja dosen adalah reliable dengan alpha sebagai berikut.

Uji reliabilitas akan dilakukan dengan metode Alpha Cronbach. Hasil uji reliabilitas untuk variabel motivasi kerja $\left(X_{1}\right)$ didapat nilai 0,729 lebih besar dari nilai $\alpha=0,6$. Begitu juga untuk hasil variabel kepemimpinan $\left(\mathrm{X}_{2}\right)$ didapat nilai 0,729 serta variabel kinerja dosen(Y) didapat nilai reliabilitas sebesar 0,729. Hal ini berarti bahwa instrumen dari ketiga variabel dinyatakan reliabel.

\section{K. Analisis Statistik Deskriptif}

Pada bagian ini dideskripsikan data hasil penelitian yang diperoleh dilapangan, baik data tentang motivasi kerja $\left(\mathrm{X}_{1}\right)$, kepemimpinan $\left(\mathrm{X}_{2}\right)$ maupun kinerja dosen $(\mathrm{Y})$. Data tersebut diperoleh dari dari hasil pengisian angket yang disebarkan kepada 35 orang responden dengan menggunakan instrumen yang dikembangkan dan dibuat sendiri oleh penulis.

Data hasil penelitian disajikan mulai variabel bebas kemudian dilanjutkan dengan variabel terikat. Distribusi frekuensi data variabel tentang motivasi kerja, kepemimpinan dan kinerja dosen dapat dilihat dalam tabel berikut : 
Tabel 4

Statistik Deskriptif

Statistics

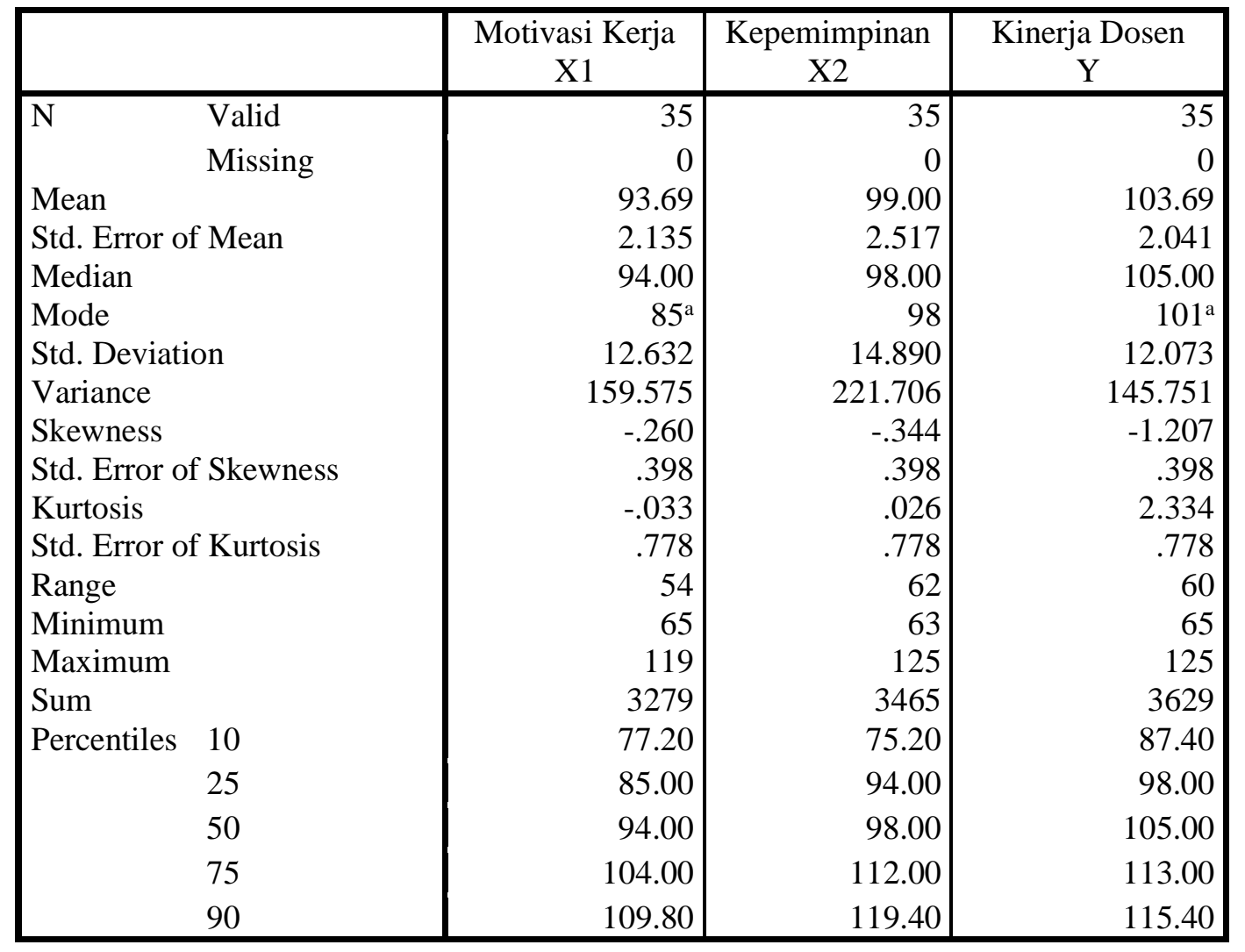

Sumber : Data diolah peneliti dengan program SPSS versi 18

a. Deskripsi Variabel Motivasi Kerja $\left(\mathrm{X}_{1}\right)$

Dari data yang diperoleh di lapangan setelah dilakukan perhitungan statistik diperoleh data motivasi kerja, yaitu skor minimum 65 dan skor maksimum 119 Sedangkan skor rata-rata sebesar 93,69, median 94,00, modus 85 standar deviasi 12,632 dan varians sebesar 159,575. Untuk mengetahui distribusi frekuensi skor motivasi kerja dapat dilihat pada tabel dan gambar histogram frekuensi berikut ini: 
Tabel 5

Distribusi Frekuensi Skor Motivasi Kerja

Motivasi Kerja (X1)

\begin{tabular}{|c|c|c|c|c|c|}
\hline & Frequency & Percent & Valid Percent & Cumulative Percent \\
\hline Valid & 65 & 1 & 2.9 & 2.9 & 2.9 \\
\hline & 68 & 1 & 2.9 & 2.9 & 5.7 \\
\hline & 70 & 1 & 2.9 & 2.9 & 8.6 \\
\hline & 82 & 1 & 2.9 & 2.9 & 11.4 \\
\hline & 83 & 2 & 5.7 & 5.7 & 17.1 \\
\hline & 84 & 1 & 2.9 & 2.9 & 20.0 \\
\hline & 85 & 3 & 8.6 & 8.6 & 28.6 \\
\hline & 87 & 1 & 2.9 & 2.9 & 31.4 \\
\hline & 88 & 2 & 5.7 & 5.7 & 37.1 \\
\hline & 91 & 3 & 8.6 & 8.6 & 45.7 \\
\hline & 93 & 1 & 2.9 & 2.9 & 48.6 \\
\hline & 94 & 1 & 2.9 & 2.9 & 51.4 \\
\hline & 95 & 2 & 5.7 & 5.7 & 57.1 \\
\hline & 96 & 2 & 5.7 & 5.7 & 62.9 \\
\hline & 98 & 1 & 2.9 & 2.9 & 65.7 \\
\hline & 100 & 2 & 5.7 & 5.7 & 71.4 \\
\hline & 101 & 1 & 2.9 & 2.9 & 74.3 \\
\hline & 104 & 1 & 2.9 & 2.9 & 77.1 \\
\hline & 105 & 1 & 2.9 & 2.9 & 80.0 \\
\hline & 107 & 1 & 2.9 & 2.9 & 82.9 \\
\hline & 108 & 1 & 2.9 & 2.9 & 85.7 \\
\hline & 109 & 2 & 5.7 & 5.7 & 91.4 \\
\hline & 111 & 1 & 2.9 & 2.9 & 94.3 \\
\hline & 113 & 1 & 2.9 & 2.9 & 97.1 \\
\hline & 119 & 1 & 2.9 & 2.9 & 100.0 \\
\hline & Total & 35 & 100.0 & 100.0 & \\
\hline
\end{tabular}

Sumber : Data diolah peneliti dengan program SPSS 18

b. Deskripsi Variabel Kepemimpinan $\left(\mathrm{X}_{2}\right)$

Dari hasil perhitungan jawaban dengan angket yang disebar kepada 35 responden, pada penelitian ini diperoleh data mengenai kepemimpinan $\left(\mathrm{X}_{2}\right)$ berupa skor minimum sebesar 63 dan skor maksimum sebesar 125 dengan skala teoritik antara 10 sampai 90. Sedangkan skor rata-rata sebesar 99.00, median 98,00, modus 98, standar deviasi 14,890 dan varians sebesar 221,706. Untuk mengetahui distribusi frekuensi kepemimpinan dapat dilihat pada tabel 10 dan histogram frekuensi skor dapat dilihat pada gambar 2 sebagai berikut: 
Tabel 6.

Distribusi Frekuensi Skor Kepemimpinan

Kepemimpinan (X2)

\begin{tabular}{|c|c|c|c|c|c|}
\hline & Frequency & Percent & Valid Percent & Cumulative Percent \\
\hline Valid & 63 & 1 & 2.9 & 2.9 & 2.9 \\
\hline & 72 & 1 & 2.9 & 2.9 & 5.7 \\
\hline & 74 & 1 & 2.9 & 2.9 & 8.6 \\
\hline & 76 & 1 & 2.9 & 2.9 & 11.4 \\
\hline & 79 & 1 & 2.9 & 2.9 & 14.3 \\
\hline & 84 & 1 & 2.9 & 2.9 & 17.1 \\
\hline & 88 & 1 & 2.9 & 2.9 & 20.0 \\
\hline & 91 & 1 & 2.9 & 2.9 & 22.9 \\
\hline & 94 & 1 & 2.9 & 2.9 & 25.7 \\
\hline & 95 & 2 & 5.7 & 5.7 & 31.4 \\
\hline & 97 & 2 & 5.7 & 5.7 & 37.1 \\
\hline & 98 & 6 & 17.1 & 17.1 & 54.3 \\
\hline & 99 & 1 & 2.9 & 2.9 & 57.1 \\
\hline & 100 & 1 & 2.9 & 2.9 & 60.0 \\
\hline & 101 & 2 & 5.7 & 5.7 & 65.7 \\
\hline & 102 & 1 & 2.9 & 2.9 & 68.6 \\
\hline & 103 & 2 & 5.7 & 5.7 & 74.3 \\
\hline & 112 & 1 & 2.9 & 2.9 & 77.1 \\
\hline & 114 & 1 & 2.9 & 2.9 & 80.0 \\
\hline & 115 & 1 & 2.9 & 2.9 & 82.9 \\
\hline & 117 & 1 & 2.9 & 2.9 & 85.7 \\
\hline & 118 & 1 & 2.9 & 2.9 & 88.6 \\
\hline & 119 & 1 & 2.9 & 2.9 & 91.4 \\
\hline & 120 & 1 & 2.9 & 2.9 & 94.3 \\
\hline & 123 & 1 & 2.9 & 2.9 & 97.1 \\
\hline & 125 & 1 & 2.9 & 2.9 & 100.0 \\
\hline & Total & 35 & 100.0 & 100.0 & \\
\hline
\end{tabular}

Sumber : Data diolah peneliti dengan program SPSS versi 18

c. Variabel Kinerja Dosen (Y)

Dari data yang diperoleh di lapangan setelah dilakukan perhitungan statistik diketahui skor minimum data kinerja dosen sebesar 65 dan skor maksimum sebesar 125 dengan skala teoritik antara 10 sampai dengan 90. Sedangkan skor rata-rata sebesar 103,69, median sebesar 105,00, modus sebesar 101, standar deviasi 12,073 standar varians 145,751 Untuk mengetahui distribusi frekuensi skor kinerja dosen dapat dilihat pada tabel 7 sebagai berikut: 
Tabel 7

Distribusi Frekuensi Skor Kinerja dosen

\begin{tabular}{|c|c|c|c|c|c|}
\hline & & Frequency & Percent & Valid Percent & Cumulative Percent \\
\hline \multirow[t]{22}{*}{ Valid } & 65 & 1 & 2.9 & 2.9 & 2.9 \\
\hline & 79 & 2 & 5.7 & 5.7 & 8.6 \\
\hline & 93 & 1 & 2.9 & 2.9 & 11.4 \\
\hline & 94 & 1 & 2.9 & 2.9 & 14.3 \\
\hline & 95 & 2 & 5.7 & 5.7 & 20.0 \\
\hline & 97 & 1 & 2.9 & 2.9 & 22.9 \\
\hline & 98 & 2 & 5.7 & 5.7 & 28.6 \\
\hline & 101 & 3 & 8.6 & 8.6 & 37.1 \\
\hline & 102 & 1 & 2.9 & 2.9 & 40.0 \\
\hline & 103 & 2 & 5.7 & 5.7 & 45.7 \\
\hline & 105 & 2 & 5.7 & 5.7 & 51.4 \\
\hline & 106 & 1 & 2.9 & 2.9 & 54.3 \\
\hline & 108 & 3 & 8.6 & 8.6 & 62.9 \\
\hline & 109 & 2 & 5.7 & 5.7 & 68.6 \\
\hline & 110 & 1 & 2.9 & 2.9 & 71.4 \\
\hline & 112 & 1 & 2.9 & 2.9 & 74.3 \\
\hline & 113 & 3 & 8.6 & 8.6 & 82.9 \\
\hline & 115 & 3 & 8.6 & 8.6 & 91.4 \\
\hline & 116 & 1 & 2.9 & 2.9 & 94.3 \\
\hline & 120 & 1 & 2.9 & 2.9 & 97.1 \\
\hline & 125 & 1 & 2.9 & 2.9 & 100.0 \\
\hline & Total & 35 & 100.0 & 100.0 & \\
\hline
\end{tabular}

Sumber : Data diolah peneliti dengan program SPSS versi 18

\section{Analisi Statistik Inferensial}

Setelah dilakukan analisis statistik deskriptif, pengujian persyaratan analisis selanjutnya dilakukan analisis statistik inferensial menggunakan teknik analisis Korelasi, Analisis Regresi Linier dan Determinasi serta varians (Anova).

\section{Analisis Korelasi}

Korelasi adalah salah satu teknik statistik yang digunakan untuk mencari hubungan antara dua variabel atau lebih. Dalam hal ini tidak ditentukan variabel mana yang mempengaruhi variabel yang lainnya. Nilai koefesien korelasi berkisar antara -1 dan 1. Semakin mendekati satu nilai absolut koefisien korelasi maka hubungan antara variabel tersebut semakin kuat, sedangkan semakin kecil 
(mendekati nol) nilai absolut koefisien korelasi maka hubungan antara variabel tersebut semakin lemah. Tanda positif atau negatif menunjukkan arah hubungan. Kuat atau lemahnya korelasi antara variabel tidak ada ukuran yang pasti. Menurut Young (1982:317), ukuran korelasi diterjemahkan sebagai berikut:

a. 0,70 - 1,00 ( baik positif atau negatif) menunjukkan adanya derajat asosiasi yang tinggi

b. 0,40 - < 0,70 (baik positif atau negatif) menunjukkan hubungan yang substansial

c. 0,20 - 0,40 (baik positif atau negatif) menunjukkan adanya korelasi rendah

d. <0,20 (baik positif atau negatif) korelasi dapat diabaikan.

Dalam SPSS, untuk mencari koefesien korelasi dan mengujiapakah korelasi tersebut sisgnifikan pada tingkat keyakinan $95 \%$ adalah sebagai berikut:

Tabel 8

Hasil Analisis Korelasi Produk Moment

Correlations

\begin{tabular}{|c|c|c|c|c|}
\hline & & $\begin{array}{c}\text { Motivasi Kerja } \\
\text { X1 }\end{array}$ & $\begin{array}{c}\text { Kepemimpinan } \\
\text { X2 }\end{array}$ & $\begin{array}{c}\text { Kinerja Dosen } \\
\mathrm{Y}\end{array}$ \\
\hline \multirow[t]{3}{*}{ Motivasi Kerja } & $\begin{array}{l}\text { Pearson } \\
\text { Correlation }\end{array}$ & 1 & $.827^{* \star}$ & $.729^{* *}$ \\
\hline & Sig. (2-tailed) & & .000 & .000 \\
\hline & $\mathrm{N}$ & 35 & 35 & 35 \\
\hline \multirow[t]{3}{*}{ Kepemimpinan } & $\begin{array}{l}\text { Pearson } \\
\text { Correlation }\end{array}$ & $.827^{\star \star}$ & 1 & $.758^{* *}$ \\
\hline & Sig. (2-tailed) & .000 & & .000 \\
\hline & $\mathrm{N}$ & 35 & 35 & 35 \\
\hline \multirow[t]{3}{*}{ Kinerja Dosen } & $\begin{array}{l}\text { Pearson } \\
\text { Correlation }\end{array}$ & $.729^{* \star}$ & $.758^{* *}$ & 1 \\
\hline & Sig. (2-tailed) & .000 & .000 & \\
\hline & $\mathrm{N}$ & 35 & 35 & 35 \\
\hline
\end{tabular}

${ }^{* *}$. Correlation is significant at the 0.01 level (2-tailed).

Sumber : Data diolah peneliti dengan program SPSS versi 18

Intreprestasi dari tabel di atas adalah :

* Korelasi antara motivasi kerja $\left(\mathrm{X}_{1}\right)$ dengan kinerja dosen $(\mathrm{Y})$ Adalah 0,827 artinya hubungan antara variabel motivasi kerja dengan kinerja dosen adalah cukup kuat dan bersipat positif (searah). Jika skor motivasi kerja naik maka skor kinerja dosen juga akan meningkat, demikian juga sebaliknya.

* Korelasi antara kepemimpinan $\left(\mathrm{X}_{2}\right)$ dengan kinerja dosen $(\mathrm{Y})$ adalah 0,729 artinya hubungan antara variabel kepemimpinan dengan kinerja dosen adalah sangat kuat dan bersipat positif (searah). Jika skor kepemimpinan naik maka skor kinerja dosen juga akan meningkat, demikian juga sebaliknya. 
* Koefesien korelasi antara kepemimpinan dengan kinerja dosen lebih kuat hubungannya dibandingkan korelasi antara motivasi kerja dengan kinerja dosen.

* Pengujian Hipotesis

Ho : Tidak terdapat hubungan antara motivasi kerja dengan kinerja dosen STMIK Kharisma Karawang.

$\mathrm{Hi}$ : Terdapat hubungan positif antara motivasi kerja dengan kinerja dosen STMIK Kharisma Karawang

Nilai Sig (2-tailed) untuk korelasi motivasi kerja $\left(\mathrm{X}_{1}\right)$ dengan kinerja dosen (Y) STMIK Kharisma Karawang adalah 0,000 dan lebih kecil dari $\alpha=0,05$, sehingga keputusannya Ho ditolak, artinya ada hubungan positipf antara motivasi kerja dengan kinerja dosen STMIK Kharisma Karawang.

Nilai sig. (2-tailed) untuk korelasi kepemimpinan $\left(\mathrm{X}_{2}\right)$ dengan kinerja dosen (Y) STMIK Kharisma Karawang adalah 0,000 dan lebih kecil dari $\alpha=0,05$, sehingga keputusannya Ho ditolak, artinya ada hubungan positif antara kepemimpinan dengan kinerja dosen STMIK Kharisma Karawang.

\section{Analisis Regresi}

Analisis Regresi digunakan untuk mengetahui besarnya pengaruh yang terjadi pada variabel motivasi kerja dan kepemimpinan terhadap kinerja dosen STMIK Kharisma Karawang.

a. Uji Linieritas dan dan signifikansi Motivasi Kerja $\left(\mathrm{X}_{1}\right)$ dengan kinerja dosen (Y)

Hasil perhitungan uji signifikansi dan linieritas regresi dapat terlihat pada tabel berikut :

Tabel 9

Hasil Analisis Regresi Motivasi Kerja (X1)

Terhadap Kinerja Dosen (Y)

Coefficients $^{\mathrm{a}}$

\begin{tabular}{|c|c|c|c|c|c|c|}
\hline \multirow{2}{*}{\multicolumn{2}{|c|}{ Model }} & \multicolumn{2}{|c|}{ Unstandardized Coefficients } & \multirow{2}{*}{$\begin{array}{c}\text { Standardized } \\
\text { Coefficients } \\
\text { Beta }\end{array}$} & \multirow[t]{2}{*}{$\mathrm{t}$} & \multirow[t]{2}{*}{ Sig. } \\
\hline & & $\mathrm{B}$ & Std. Error & & & \\
\hline \multirow[b]{2}{*}{1} & (Constant) & 38.422 & 10.764 & & 3.569 & .001 \\
\hline & $\begin{array}{l}\text { Motivasi Kerja } \\
(\mathrm{X} 1)\end{array}$ & .697 & .114 & .729 & 6.116 & .000 \\
\hline
\end{tabular}

a. Dependent Variable: Kinerja Dosen $(\mathrm{Y})$

Dari tabel pengolahan data tersebut didapat persamaan regresi linier sederhana $: \ddot{\mathbf{Y}}=\mathbf{3 8 , 4 2 2}+\mathbf{0 , 6 9 7}\left(\mathrm{X}_{1}\right)+\mathbf{e}$, dengan taraf signifikansi lebih kecil dari 0,05 . Dengan demikian dapat dikatakan pengaruh motivasi kerja terhadap kinerja dosen signifikan dan positif, artinya semakin baik motivasi kerja semakin meningkat kinerjanya, demikian juga sebaliknya. Sedangkan untuk melihat koefesien korelasi dan koefesien determinasi terlihat pada tabel berikut : 
Tabel 10

Hasil Analisis Koefesien Korelasi dan Koefesien Determinasi

Motivasi Kerja Terhadap Kinerja Dosen

Model Sumamary

\begin{tabular}{|l|r|r|r|r|}
\hline Model & \multicolumn{1}{|c|}{$\mathrm{R}$} & R Square & Adjusted R Square & Std. Error of the Estimate \\
\hline 1 & $.729^{\mathrm{a}}$ & .531 & .517 & 8.389 \\
\hline
\end{tabular}

Predictors: (Constant), Motivasi Kerja $\left(\mathrm{X}_{1}\right)$

Dari tabel tersebut didapat koefesien korelasi sebesar 0,729 atau 72,9\% dan koefesien determinasi sebesar 0,531 atau 53,10\%. Artinya keeratan hubungan variabel motivasi kerja terhadap kinerja dosen adalah kuat dan variasi pengaruh yang dapat dijelaskan oleh motivasi kerja terhadap kinerja dosen 53,10\%.

b. Uji Kepemimpinan Linieritas dan signifikansi Kepemimpinan $\left(\mathrm{X}_{2}\right)$ terhadap Kinerja Dosen (Y)

Hasil perhitungan uji signifikansi dan linieritas regresi dapat terlihat pada tabel berikut :

Tabel 11

Hasil Analisis Regresi Kepemimpinan $\left(\mathrm{X}_{2}\right)$ terhadap Kinerja Dosen (Y) Coefficients $^{\mathrm{a}}$

\begin{tabular}{|c|c|c|c|c|c|c|}
\hline \multirow{2}{*}{\multicolumn{2}{|c|}{ Model }} & \multicolumn{2}{|c|}{ Unstandardized Coefficients } & \multirow{2}{*}{$\begin{array}{c}\begin{array}{c}\text { Standardized } \\
\text { Coefficients }\end{array} \\
\text { Beta }\end{array}$} & \multirow[t]{2}{*}{$\mathrm{t}$} & \multirow[t]{2}{*}{ Sig. } \\
\hline & & $B$ & Std. Error & & & \\
\hline \multirow[b]{2}{*}{1} & (Constant) & 42.865 & 9.218 & & 4.650 & .000 \\
\hline & $\begin{array}{l}\text { Kepemimpinan } \\
(\mathrm{X} 2)\end{array}$ & .614 & .092 & .758 & 6.670 & .000 \\
\hline
\end{tabular}

a. Dependent Variable: Kinerja Dosen (Y)

Darri tabel pengolahan data tersebut didapat persamaan regresi linier sederhana: $\ddot{\mathbf{Y}}=\mathbf{4 2 , 8 6 5}+\mathbf{0 , 6 1 4}\left(\mathrm{X}_{2}\right)+\mathbf{e}$, dengan taraf signifikansi lebih kecil dari 0,05. Dengan demikian dapat dikatakan pengaruh kepemimpinan terhadap kinerja dosen signifikan dan positif, artinya semakin tinggi kepemimpinan semakin meningkat kinerja dosen, demikian juga sebaliknya. Sedangkan untuk melihat koefesien korelasi dan koefesien determinasi terlihat pada tabel berikut :

Tabel 12

Hasil Analisis Koefesien Korelasi dan Koefesien Determinasi Kepemimpinan $\left(\mathrm{X}_{2}\right)$ Terhadap Kinerja Dosen $(\mathrm{Y})$

Model Summary

\begin{tabular}{|l|r|r|r|r|}
\hline Model & \multicolumn{1}{|c|}{$\mathrm{R}$} & \multicolumn{1}{|c|}{ R Square } & $\begin{array}{c}\text { Adjusted R } \\
\text { Square }\end{array}$ & Std. Error of the Estimate \\
\hline 1 & $.758^{\mathrm{a}}$ & .574 & .561 & 7.997 \\
\hline
\end{tabular}

a. Predictors: (Constant), Kepemimpinan $\left(\mathrm{X}_{2}\right)$ 
Dari tabel tersebut didapat koefesien korelasi sebesar 0,758 atau $75,8 \%$ dan koefesien determinasi sebesar 0,574 atau 57,4\%. Artinya keeratan hubungan variabel kepemimpinan terhadap kinerja dosen adalah kuat dan variasi pengaruh yang dapat dijelaskan oleh kepemimpinan terhadap kinerja dosen 57,4\%.

c. Uji Motivasi Kerja dan Kepemimpinan Linieritas dan Signifikansi Motivasi Kerja dan Kepemimpinan bersama-sama terhadap Kinerja Dosen (Y)

Hasil perhitungan uji signifikansi dan linieritas regresi dapat terlihat pada tabel berikut :

Tabel 13

Hasil Analisis Regresi Motivasi Kerja dan Kepemimpinan

Terhadap Kinerja Dosen

Coefficients $^{\mathrm{a}}$

\begin{tabular}{|c|c|c|c|c|c|c|}
\hline \multirow[t]{2}{*}{ Model } & \multicolumn{3}{|c|}{ Unstandardized Coefficients } & \multirow{2}{*}{$\frac{\text { Standardized Coefficients }}{\text { Beta }}$} & \multirow[t]{2}{*}{$\mathrm{t}$} & \multirow[t]{2}{*}{ Sig. } \\
\hline & $B$ & & Std. Error & & & \\
\hline \multirow{3}{*}{1} & (Constant) & 35,367 & 10,081 & & 3,508 & ,001 \\
\hline & Motivasi Kerja (X1) & ,309 & ,188 & ,324 & 1,643 &, 110 \\
\hline & Kepemimpinan (X2) & ,397 & 160 & ,490 & 2,488 & ,018 \\
\hline
\end{tabular}

a. Dependent Variable: Kinerja Dosen (Y)

Dari tabel pengolahan data tersebut didapat persamaan regesi linier sederhana yaitu : $\ddot{\mathbf{Y}}=35,367+0,309\left(\mathrm{X}_{1}\right)+\mathbf{0}, 397\left(\mathrm{X}_{2}\right)+\mathrm{e}$,

Dari persamaan ini dapat diartikan bahwa setiap peningkatan satu unit variabel $\mathrm{X}_{1}$ dengan menjaga $\mathrm{X}_{2}$ konstan menyebabkan variabel $\mathrm{Y}$ bertambah nilainya 0,309 unit. Sedangkan setiap peningkatan satu unit nilai variabel $X_{2}$ dengan menjaga $\mathrm{X}_{1}$ konstan menyebabkan variabel $\mathrm{Y}$ bertambah nilainya 0,397 unit dengan konstanta 35,367. Dari hasil perhitungan regresi linier berganda tersebut terbukti kenaikan $\mathrm{X}_{1}$ (motivasi kerja) dan $\mathrm{X}_{2}$ (kepemimpinan) akan diikuti juga peningkatan kinerja dosen.

Dari tabel coefficients didapat nilai standardized coefficients beta untuk $\mathrm{X}_{1}$ (motivasi kerja) sebesar 0,324 dan $\mathrm{X}_{2}$ (kepemimpinan) sebesar 0,490 dengan nilai signifikansi untuk $X_{1}$ sebesar 0,110 sedangakn $X_{2}$ sebesar 0,018. Hal ini berarti bahwa dari kedua variabel $X_{1}$ dan $X_{2}$ yang lebih banyak memberikan pengaruh terhadap kinerja dosen $(\mathrm{Y})$ adalah $\mathrm{X}_{2}$ (kepemmpinan).

Dari hasil perhitungan statistik tersebut, penulis dapat menguraikan bahwa kinerja dosen lebih banyak dipengaruhi oleh kepemimpinan. Karena kepemimpinan adalah orang yang berada di garis terdepan yang mengkoordinasikan upaya meningkatkan pembelajaran yang bermutu serta seorang tenaga fungsional dosen yang diberikan tugas untuk memimpin suatu perguruan tinggi dimana diselenggarakan proses belajar mengajar atau tempat dimana terjadi interaksi antara dosen yang memberikan materi kuliah dan mahasiswa yang menerima pelajaran.

Kepemimpinan berarti memiliki kompetensi yang baik yang sudah sesuai dengan standar yang ditetapkan kovertis, otomatis akan mampu mengelola perguruan tinggi dengan motivasi kerja baik. Dengan demikian akan memberi pengaruh terhadap kinerja dosen (kinerja dosen meningkat). 
3. Koefesien Determinasi

Untuk menentukan koefesien determinasi, gunanya untuk mengukur seberapa besar pengaruh nilai suatu variabel independen dapat dijelaskan terhadap perubahan variabel dependen. Hasil perhitungan SPSS menunjukkan bahwa nilai koefesien determinasi tersebut ditunjukkan pada tabel berikut :

Tabel 14

Hasil Analisis Koefisien Korelasi dan Koefesien Determinasi Motivasi Kerja dan Kepemimpinan terhadap Kinerja Dosen

\begin{tabular}{|l|r|r|r|r|}
\hline Model & $\mathrm{R}$ & R Square & \multicolumn{1}{|c|}{$\begin{array}{l}\text { Adjusted } \\
\text { R Square }\end{array}$} & \multicolumn{1}{c|}{ Std. Error of the Estimate } \\
\hline 1 & .779 & .607 & .583 & 7.799 \\
\hline
\end{tabular}

a. Predictors: (Constant), Kepemimpinan, Motivasi Kerja

Interprestasi :

Koefesien determinasi R Square adalah 0,607, hal ini berarti 60,7\% variasi nilai skor varabel kinerja dosen bisa dijelaskan secara bersama-sama oleh motivasi kerja dan kepemimpinan dalam model regresi. Sisanya 30,30\% dijelaskan oleh faktor lain (e). Sedangkan nilai R (korelasi/hubungan sebesar 0,779 artinya hubungan antara $\mathrm{X}_{1}$ (motivasi kerja) dan $\mathrm{X}_{2}$ ( kepemimpinan) terhadap $\mathrm{Y}$ ( kinerja dosen) sangat kuat. Untuk nilai Adjusted R Square sebesar 0,583, hal ini menunjukkan sejauh mana faktor $\mathrm{X}_{1}$ (motivasi kerja) dan $\mathrm{X}_{2}$ (kepemimpinan) secara bersamasama mempengaruhi perubahan Y (kinerja dosen) dalam hal ini faktor motivasi kerja dan kepemimpinan secara bersama-sama mempengaruhi kinerja dosen.

\section{Pengujian Hipotesis Statistik}

Pengujian hipotesis dimaksudkan untuk mengetahui apakah hipotesis nol $\left(\mathrm{H}_{0}\right)$ yang diajukan diterima atau ditolak pada tingkat signifikan tertentu. Pengujian hipotesis statistik menggunakan teknik analisis regresi dan korelasi berganda.

a. Hipotesis Pertama : Terdapat hubungan positif motivasi kerja terhadap kinerja dosen STMIK Kharisma Karawang

Hipotesis :

$\mathrm{H}_{0}: \mathrm{b}_{1}=0$, tidak terdapat pengaruh motivasi kerja $\left(\mathrm{X}_{1}\right)$ terhadap kinerja dosen

(Y) STMIK Kharisma Karawang

$\mathrm{H}_{1}: \mathrm{b}_{1} \neq 0$, terdapat pengaruh motivasi kerja $\left(\mathrm{X}_{1}\right)$ terhadap kinerja dosen $(\mathrm{Y})$ STMIK Kharisma Karawang

Kreteria pengujian

Terima Ho, sig. $\mathrm{t} \geq 0,05$

Tolak Ho, sig. $\mathrm{t}<0,05$

Dari hasil pengujian hipotesis pada tabel 12 dimana nilai sig t sebesar 0,000 lebih kecil dari tingkat sisgnifikan $5 \%(\alpha=0,05)$, sehingga kesimpulannya Ho ditolak dan menerima $\mathrm{H}_{1}$. Artinya terdapat hubungan positif antara motivasi kerja $\left(\mathrm{X}_{1}\right)$ terhadap kinerja dosen (Y) STMIK Kharisma Karawang. 
b. Hipotesis Kedua : Terdapat Pengaruh Kepemimpinan Terhadap Kinerja Dosen STMIK Kharisma Karawang

Hipotesis :

$\mathrm{H}_{0}: \mathrm{b}_{1}=0$, tidak terdapat pengaruh kepemimpinan $\left(\mathrm{X}_{2}\right)$ terhadap kinerja dosen (Y) STMIK Kharisma Karawang

$\mathrm{H}_{1}: \mathrm{b}_{1} \neq 0$, terdapat pengaruh kepemimpinan $\left(\mathrm{X}_{2}\right)$ terhadap kinerja dosen $(\mathrm{Y})$ STMIK Kharisma Karawang

Kreteria pengujian

Terima Ho, sig. $\mathrm{t} \geq 0,05$

Tolak Ho, sig. $\mathrm{t}<0,05$

Dari hasil pengujian hipotesis pada tabel 14 dimana nilai sig t sebesar 0,000 lebih kecil dari tingkat sisgnifikan $5 \%(\alpha=0,05)$, sehingga kesimpulannya Ho ditolak dan menerima $\mathrm{H}_{1}$. Artinya terdapat hubungan positif antara kepemimpinan $\left(\mathrm{X}_{1}\right)$ terhadap kinerja dosen (Y) STMIK Kharisma Karawang.

c. Hipotesis Ketiga : Terdapat hubungan positif motivasi kerja dan kepemimpinan secara bersama-sama terhadap kinerja dosen STMIKKharisma Karawang.

Hipotesis :

$\mathrm{H}_{0}: \mathrm{b}_{1}=0$, tidak terdapat pengaruh motivasi kerja (X1) dan kepemimpinan $\left(\mathrm{X}_{2}\right)$ secara bersama-sam terhadap kinerja dosen (Y) STMIK Kharisma Karawang

$\mathrm{H}_{1}: \mathrm{b}_{1} \neq 0$, terdapat pengaruh motivasi kerja (X1) dan kepemimpinan $\left(\mathrm{X}_{2}\right)$ secara bersama-sama terhadap kinerja dosen (Y) STMIK Kharisma Karawang

\section{Kreteria pengujian}

Terima Ho, sig. F $\geq 0,05$

Tolak Ho, sig. $\mathrm{F}<0,05$

Dari hasil pengujian hipotesis dimana nilai sig t sebesar 0,000 lebih kecil dari tingkat sisgnifikan $5 \%(\alpha=0,05)$, sehingga kesimpulannya Ho di tolak dan menerima H1. Artinya terdapat hubungan positif pengaruh motivasi kerja dan kepemimpinan terhadap kinerja dosen STMIK Kharisma Karawang.

Tabel 15

\section{Hasil Analisis Uji F}

ANOVA $^{\mathrm{a}}$

\begin{tabular}{|rl|r|r|r|r|r|}
\hline Model & Sum of Squares & Df & Mean Square & F & Sig. \\
\hline \multirow{2}{*}{1} & Regression & 3009,292 & 2 & 1504,646 & 24,739 &, $000^{\mathrm{b}}$ \\
& Residual & 1946,251 & 32 & 60,820 & & \\
& Total & 4955,543 & 34 & & & \\
\hline
\end{tabular}

a. Dependent Variable: Kinerja Dosen $(Y)$

b. Predictors: (Constant), Kepemimpinan (X2), Motivasi Kerja (X1)

Sumber : Data diolah peneliti dengan program SPSS versi 18 
Berdasarkan hasil perhitungan dari tabel di atas diperoleh F hitung 24,739 dan nilai signifikansi 0,000 yang lebih kecil dari $\alpha 0,05$ artinya terdapat pengaruh motivasi kerja dan kepemimpinan terhadap kinerja dosen secara bersama-sama.

Dari hasil perhitungan statistik, maka hipotesis yang diajukan dapat diterima $\left(\mathrm{H}_{1}: \mathrm{b}_{1} \neq 0\right.$, terdapat pengaruh motivasi kerja $\left(\mathrm{X}_{1}\right)$ dan kepemimpinan $\left(\mathrm{X}_{2}\right)$ terhadap kinerja dosen (Y) secara simultan).

\section{N. Interprestasi Hasil Penelitian}

Hasil analisis statistik yang dilakukan dengan bantuan program SPSS meliputi analisis Regresi, Analisis Korelasi Product Moment, Determinasi, serta prediksi yang menunjukkan hal-hal sebagai berikut:

Adapun interprestasi terhadap hasil analisis tersebut adalah sebagai berikut:

1. Variabel motivasi kerja $\left(X_{1}\right)$ dan Kepemimpinan $\left(X_{2}\right)$ mempunyai korelasi yang kuat dan positif terhadap kinerja dosen artinya bila variabel motivasi kerja dan kepemimpinan meningkat maka akan mengakibatkan meningkatnya kinerja dosen, begitu pula sebaliknya, apabila variabel motivasi kerja dan kepemimpinan menurun maka kinerja dosen juga menurun.

2. Bahwa antara variabel motivasi kerja dan kepemimpinan mempunyai hubungan yang signifikan dengan variabel kinerja dosen, dimana terdapat korelasi sebesar 0,827 termasuk pada katagori tingkat hubungan yang sangat kuat dan korelasi tersebut signifikan, karena setelah dikonsultasikan dengan nilai (r) pada tabel kritik (r) hitung lebih besar dari nilai (r) tabel.

3. Hasil perhitungan menunjukkan bahwa konstanta sebesar 35,367 menyatakan bahwa jika mengabaikan motivasi kerja dan kepemimpinan maka skor kinerja dosen adalah 35,367. Koefisien $\mathrm{X}_{1}$ sebesar 0,309 menyatakan bahwa setiap penambahan satu satuan skor motivasi kerja akan meningkatkan skor kinerja dosen sebesar 0,309 dengan menjaga skor kepemimpinan $\left(\mathrm{X}_{2}\right)$ tetap/konstan. Koefisien regresi $\mathrm{X}_{2}$ sebesar 0,397 menyatakan bahwa setiap penambahan satu satuan skor kepemimpinan akan meningkat skor kinerja dosen sebesar 0,397 Dengan menjaga skor motivasi kerja tetap/konstan.

4. Koefisien Determinasi $\left(\mathrm{R}^{2}\right)$ sebesar 0,607 hal ini berarti $60,7 \%$ variasi nilai skor variabel kinerja dosen bisa dijelaskan secara bersam-sama oleh motivasi kerja dan kepemimpinan dalam model regresi, sisanya 39,3\% dijelaskan oleh faktor lain.

\section{O. Pembahasan Hasil Penenelitian}

Hasil analisis korelasi dan regresi antara variabel motivasi kerja terhadap kinerja dosen memberikan petunjuk bahwa koefisien regresi variabel motivasi kerja $\left(\mathrm{X}_{1}\right)$ 0,309 atau sama 30.9\% dapat diprediksi perubahan pada variabel kinerja dosen (Y) dan koefesienkorelasi secara parsial 0,827 dengan tingkat signifikansi 5\% artinya variabel ini memiliki pengaruh dan hubungan positif serta determinasi yang signifikan (berarti). Hasil penelirian ini menjadi dasar bagi pencapaian kinerja dosen melalui variabel motivasi kerja. Dengan demikian kinerja dosen tidak akan tercapai apabila motivasi kerja tidak dilaksanakan dengan sesungguhnya, begitu pula sabaliknya.

Hasil analisis korelasi dan regresi antara variabel kepemimpinan terhadap kinerja dosen memberikan petunjuk, bahwa koefisien regresi variabel 
kepemimpinan $\left(\mathrm{X}_{2}\right) \quad 0,758$ atau sama $75.7 \%$ dapat memprediksi perubahan pada variabel kinerja dosen (Y) dan tingkat signifikansi sebesar 5\% artinya variabel ini memiliki pengaruh dan hubungan positif serta determinasi yang signifikan (berarti). Hasil penelitian ini menjadi dasar bagi pencapaian kinerja dosen melalui variabel kepemimpinan. Dengan demikian kinerja dosen tidak akan tercapai apabila kepemimpinan tidak dilaksanakan dengan sesungguhnya, begitu pula sebaliknya.

Hasil analisis regresi berganda dan korelasi antara variabel motivasi kerja dan kepemimpinan terhadap kinerja dosen memberikan pentunjuk, bahwa model persamaan regresi $\ddot{\mathbf{Y}}=\mathbf{3 5}, \mathbf{3 6 7}+\mathbf{0}, \mathbf{3 0 9}\left(\mathrm{X}_{1}\right)+\mathbf{0}, \mathbf{3 9 7}\left(\mathrm{X}_{2}\right)+\mathbf{e}$, dengan koefesien korelasi secara simultan sebesar 0,779 didukung oleh tingkat signifikansi sebesar $5 \%$. Temuan ini menunjukkan bahwa terdapat hubungan yang berarti antara variabel motivasi kerja dan kepemimpinan terhadap kinerja dosen secara bersama-sama dimana $77.9 \%$ variasi yang terjadi pada kinerja dosen dapat dijelaskan oleh variabel motivasi kerja dan kepemimpinan. Artinya kinerja dosen memiliki arah hubungan positif dari kedua variabel motivasi kerja dan kepemimpinan, dengan demikian bila terjadi perubahan kearah positif dari kedua variabel bebas tersebut akan memberikan pengaruh yang positif pula pada kinerja dosen STMIK Kharisma Karawang

\section{P. Kesimpulan dan Saran}

\section{Kesimpulan}

Didasarkan dari pengolahan data dan pembahasan pada bab terdahulu, maka dapat ditarik kesimpulan sebagai berikut:

a. Pengujian hipotesis, variabel motivasi kerja mempunyai pengaruh terhadap kinerja dosen. Adapun nilai korelasinya 0,827 artinya hubungan antara motivasi kerja terhadap kinerja dosen adalah kuat dengan nilai koefisien determinasi $\left(\mathrm{R}^{2}\right)$ sebesar 0,607 . Dengan demikian apabila dosen menjalankan tugas dengan baik dan profesional, maka dengan sendirinya akan meningkat kinerjanya. Hal tersebut dapat dibuktikan dengan hasil perhitungan persamaan regresi, dimana setiap ada peningkatan dari motivasi kerja persepuluh unit maka kinerja dosen juga mengalami peningkatan.

b. Demikian juga variabel kepemimpinan mempunyai pengaruh terhadap kinerja dosen Adapun nilai korelasinya 0,729 artinya hubungan antara kepemimpinan terhadap kinerja dosen adalah kuat dengan nilai koefisien determinasi $\left(\mathrm{R}^{2}\right)$ sebesar 0,607. Dengan demikian pemimpin dalam menjalankan tugas harus membawa perubahan yang lebih baik, maka dengan sendirinya akan meningkat kinerja dosen. Hal tersebut dapat dibuktikan dengan hasil perhitungan persamaan regresi, dimana setiap ada peningkatan dari kepemimpinan persepuluh unit maka kinerja dosen juga mengalami peningkatan.

c. Dari hasil koefesien korelasi $\mathrm{R}=0,779$ artinya hubungan antara variabel motivasi kerja dan kepemimpinansangat erat dan searah (korelasi positif) sebesar 77,9\%

d. Diperoleh koefesien determinasi $\left(R^{2}=0,607\right)$. hasil ini secara statistik cukup signifikan artinya $60,7 \%$ secara bersama-sama dapat menjelaskan pengaruh dari variabel motivasi kerja $\left(\mathrm{X}_{1}\right)$ dan kepemimpinan $\left(\mathrm{X}_{2}\right)$ dengan kinerja dosen $(\mathrm{Y})$, sedangkan sisanya 30,3\%

\section{Saran} dapat dijelaskan oleh variabel yang lain yang tidak dimasukkan dalam penelitian ini.

a. Agar pihak pimpinan terus menerus berupaya untuk memberikan motivasi kepada dosen agar dalam bekerja dan memberikan materi kuliah lebih baik lagi.

b. Diharapkan dilakukan penelitian lanjutan yang mengkaji masalah-masalah Kinerja Dosen dan faktor-faktor yang mempengaruhi dengan menggunakan berbagai variabel bebas lainnya. 


\section{DAFTAR PUSTAKA}

Hani Handoko, 2002 Manajemen Personalia dan Sumber Daya Manusia, Liberty, Yogyakarta

Hasibuan, 2003 Organisasi dan Motivasi, Bumi Aksara, Jakarta

Husen Umar, 2000, Metode Penelitian untuk Skripsi dan Tesis Bisnis, PT. Raja Raja Grafindo Persada, Jakarta

Haryono, Suyono, 2004 Metode Penelitian dan Bisnis. Jakarta

H. Hadawi Nawawi, 2000. Kepemimpinan yang Efektif, Gajah Mada University Press, Yogyakarta

Mangkunegara, A.P. 2000. Manajemen Sumber Daya Manusia. PT. Remaja Rosdakarya, Bandung.

Nawawi H. Hadari , 2005 Manajemen Sumber Daya Manusia untuk bisnis yang kompetitif, Gajah Mada University Press, Yogyakarta

Prawirosentono, 2001, Kebijakan Kinerja Pegawai , BPFE, Yogyakarta

Siagian, P Sondang. 2005, Manajemen Sumber Daya Manusia, Bumi Aksara, Jakarta.

Siswoyo Haryono, 2011 Intisari Teori Kepemimpinan, PT Intermedia Personalia Utama Bekasi Jakarta.

Suleman Sukmalana, 2005, Langkah dan Kebijakan Evaluasi Kinerja, Universitas Tridinanti Palembang 